\title{
Instrumental, Strategic and Political Conception of Corporate Social Responsibility
}

\author{
Seçil Deren Van Het Hof, Akdeniz University, Turkey \\ Sibel Hoştut, Akdeniz University, Turkey
}

\begin{abstract}
The Corporate Social Responsibility (CSR) literature defines instrumental, strategic and political approaches to CSR. The strategic approach to CSR in transnational corporations goes beyond the customer orientated short time issue management, persuasion and financial performance, but emphasizes a long time perspective based on planned, implemented and evaluated projects to create business value. The research in this paper focuses on the corporate communication directors conception of corporate social responsibility. Participants from transnational and Turkish national corporations have been interviewed and qualitatively analysed. Thefindingsshowthatallinterviewedparticipantsare enthusiastic about the concept of social responsibility. They define CSR as the "raison d'etre of the company" or "the sine qua non of sustainability is social responsibility”. Two of three Turkish national corporations' CSR conception can be defined as a stage between instrumental and strategic, because CSR in these corporations is more customer orientated with limited or short time influence at the one side, but also implemented for sustainability and to create business value on the other side. The CSR perspective of a Turkish national company based on a farmers union established half a century in order to serve the interests of the local community and stimulate development is clearly political. The conception of sustainability and responsiveness to stakeholders was inherent in the establishment of this particular firm. We conclude that there is a remarkable agreement between the CSR directors' perspective and the firm's organizational behaviour and that the cases follow the classification described in the literature to some extent.
\end{abstract}

Keywords: Instrumenal CSR, Strategic CSR, Political CSR, Corporate Communication Professionals 


\section{Introduction}

There is no clear-cut and concrete definition of CSR as CSR contains almost everything of public concern. Everyone has his or her own answer to and understanding of CSR (Tench, Sun \& Jones, 2012,p. 6). The European Commission (2001) regards CSR as "a concept whereby companies integrate social and environmental concerns in their business operations and in their interaction with their stakeholders on a voluntary basis". This definition comprises the economic, social, environmental, stakeholder and voluntariness dimensions of CSR developed through a content analysis of existing CSR definitions by Dahlsrud (2008). According to Bhattacharyya (2010, p. 82) doing corporate social responsibility (CSR) activities today is becoming a necessity for business organizations rather than just remaining a choice. In the business environment of Turkey, there is a confusion over the definition of CSR which reflects itself on the practices of CSR. However, on the part of the business community, a strong incentive for efforts developing business and society is observed. The sponsorship activities as well as social projects organized with Non-Governmental Organizations (NGOs) are among those efforts (Göcenoğlu \& Onan, 2008, p. 3). Most business groups in Turkey have an associated foundation named after the founding family. Family foundations accept donations only from family controlled businesses and individual family members. Group companies allocate a percentage of their profits to the foundation, for redistribution to social projects (Ararat, 2008, p. 277). Corporate social responsibility refers to a variety of charitable activities, taking initiatives predominantly in areas like education and health, but also guiding women to business life, making acommodation facilities for street children and animals. Despite the rich tradition of foundations, legal and fiscal frameworks that support corporate philanthropy are relatively weak (Ararat, 2008, p. 277). According to studies of CSR practices of the Turkish private sector, there is a notable gap between the number of companies with their own ethical codes and CSR strategies and the number of the companies doing CSR reporting (Orhaner \& Dogan, 2010, p. 48). Sustainability reporting has recently become more important because, since the first quarter of 2014 Borsa Istanbul Stock Exchange (BIST) has a new listing called BIST Sustainability Index. This index is based on environmental, social and governance issues of the companies in order to encourage investment in sustainable companies (Hoştut \& Deren Van Het Hof, 2015, p. 117).

Just as there is no consensus on the definition and the boundaries of CSR, there is still no emerging consensus on the most appropriate classification of CSR theories (Frynas \& 
Stephens, 2014, p. 3). Previous studies offered different classifications of CSR practices. Lantos (2001) distinguishes between ethical, altruistic and strategic CSR, Vogel (2005) between strategic, defensive, and altruistic or public-spirited, Porter and Kramer (2006) between responsive and strategic CSR, Bhattacharyya (2010) between strategic and nonstrategic CSR activities, Makinen and Kourula (2012) between classic, instrumental and new political CSR, Bansal, Jiang and Jung (2015) between strategic and tactical CSR, Elving et.al (2015) between instrumental/strategic and communicative action.

This investigation examines the CSR behavior and policies at the organizational level, in the frame of corporate communication professionals. To explain corporations' CSR policies and activities the framework of instrumenal, strategic and political conceptions of CSR was used.

\section{The Classification of CSR}

To distinguish between one-time, longitudinal and ethical CSR activities or between corporate citizenship, corporate sustainability and social benefits the classification between instrumental, strategic and political CSR has been made. Table 1 presents a summary of the main characteristics of these approaches. 
Table 1. Conceptions of CSR in large Corporations

\begin{tabular}{|c|c|c|c|}
\hline & $\begin{array}{l}\text { Instrumental } \\
\text { CSR }\end{array}$ & Strategic CSR & Political CSR \\
\hline Agent & Company & $\begin{array}{l}\text { Company, NGOs, } \\
\text { Government Units }\end{array}$ & Company \\
\hline $\begin{array}{l}\text { Label of Person } \\
\text { who performs } \\
\text { CSR }\end{array}$ & $\begin{array}{l}\text { PR or Marketing } \\
\text { Manager }\end{array}$ & CSR Manager & $\begin{array}{l}\text { CSR Manager or } \\
\text { Corporate Relations } \\
\text { Manager }\end{array}$ \\
\hline $\begin{array}{l}\text { Third Party } \\
\text { Contribution }\end{array}$ & Seldom & Often & Seldom \\
\hline CSR Strategy & $\begin{array}{l}\text { Issue } \\
\text { management }\end{array}$ & $\begin{array}{l}\text { Corporate strategy based } \\
\text { on corporate philosophy }\end{array}$ & $\begin{array}{l}\text { Integral to } \\
\text { organizational identity }\end{array}$ \\
\hline CSR Target & \begin{tabular}{|l} 
Financial \\
Performance \\
\end{tabular} & Corporate sustainability & Corporate citizenship \\
\hline CSR Policy & Defensive & Solution Oriented & Innovative \\
\hline Interval & Short-term & Long-term & Long-term \\
\hline Resourse & $\begin{array}{l}\text { Limited } \\
\text { resources }\end{array}$ & Autonomous resources & Adjustable Resources \\
\hline Field of Influence & Limited & Extensive & Contingent \\
\hline $\begin{array}{l}\text { Corporate } \\
\text { Orientation }\end{array}$ & Reaktif & Proaktif & $\begin{array}{l}\text { Organizational } \\
\text { behaviour }\end{array}$ \\
\hline $\begin{array}{l}\text { Corporate } \\
\text { Governance Style }\end{array}$ & $\begin{array}{l}\text { Customer } \\
\text { oriented }\end{array}$ & $\begin{array}{l}\text { Corporate Governance } \\
\text { oriented }\end{array}$ & Stakeholders oriented \\
\hline $\begin{array}{l}\text { Stakeholder } \\
\text { Relations }\end{array}$ & Short-term & Long-term & Long-term \\
\hline Research & $\begin{array}{l}\text { Secondary } \\
\text { sources }\end{array}$ & $\begin{array}{l}\text { Secondary and Primary } \\
\text { sources }\end{array}$ & $\begin{array}{l}\text { Secondary and Primary } \\
\text { sources }\end{array}$ \\
\hline $\begin{array}{l}\text { Primary } \\
\text { Stakeholder }\end{array}$ & Customers & Public opinion & $\begin{array}{l}\text { Shareholders and } \\
\text { constituents }\end{array}$ \\
\hline $\begin{array}{l}\text { Communication } \\
\text { Target }\end{array}$ & Persuasion & Reputation & $\begin{array}{l}\text { Organizational } \\
\text { Philosophy }\end{array}$ \\
\hline
\end{tabular}

Developed from Scherer and Palazzo (2011, p. 908); Bansal, Guoliang and Jae (2015, p. 70),

Matten and Crane (2005)

\section{Instrumental CSR}

A common way to start the instrumental CSR discussion is to refer to Milton Friedman's view on CSR, classified in the liberal doctrine of CSR (Mäkinen \& Kourula, 2012, p. 661-662). For 
Friedman (1970), CSR is the maximization of shareholder value within the rules of the law and ethical context. According to him the company management is responsible to the owner and shareholder, who expect maximal profit. In this view instrumental CSR is defined as CSR activities mainly oriented towards improving stakeholder relationships in the shortterm. This emphasizes that CSR is used to improve efficiency in the quest for financial performance (Jones \& Wicks, 1999, Barnett \& Salomon, 2006, Husted \& Salazar, 2006). Actions can be implemented relatively quickly, are easy to understand and implement, and often reversible. Aktivities do not require major resources, procedural or structural modifications and are not idiosyncratic to the firm. Therefore these actions can be easily imitated by competitors and their competitive advantage can be quickly erode (Bansal et al, 2015, p. 70). If CSR continues to be seen as nothing more than corporate philanthropy, all CSR applications might be considered as marketing tools with short-term advancesgenerally far away from strategic CSR with long term targets (Orhaner \& Doğan, 2010, p. 15, 44). For example, donating a small percentage of profits to charities or supporting special purpose NGOs can be planned and executedquickly. Corporations can even decide to initiate new donations within the last few weeks of year inorder to report an appealing achievement to the media and through its annual CSR report (Bansal et al., 2015, p. 70). According to a strudy by Committee Encouraging Corporate Philanthropy (2014, p. 18) a company's giving budget usually funds a range of cause areas. In 2013, 96\% of companies supported educational causes and 91\% supported health and social services. Culture and arts ranked third, with $83 \%$ of companies. A surprising statistic is given that the average company budget gave only $5 \%$ to arts initiatives. This indicates that many companies support arts with small dollar amounts. Companies on average direct the highest proportion of their grants (28\%) to education (K-12 and Higher), followed closely by health and social services $(27 \%)$. It is noted that corporate charitable contributions are used quickly to remedy a negative business image, caused in environmental and social areas (Chen et al, 2008). Short-time CSR practices are easily communicable to the public. However, they are not necessarily in the focus of the companies' activities and are often the first to be cancelled in times of economic crisis. They start and end with a fixed goal and budgetand do not influence the company as a whole (Martinuzzi \& Krumay, 2013, p. 430). 


\section{Strategic CSR}

Strategic CSR activities go beyond the common understanding of instrumental CSR. The strategic view of CSR is defined as corporate social activities that require long time horizons, large resource commitments, and significant adjustments to organizational structures (Bansal et al., 2015, p. 70). 'Rethink your business' is the motto of strategic CSR (Martinuzzi \& Krumay, 2013, p. 434). To help the corporation towards achieving its mission and vision it should be proactive and planned, be long term in perspective and require sacrifice of substantial amount of resources. Otherwise it is unlike any serious business activity (Bhattacharyya, 2010, 90-92). The ideal company has a wide scale of CSR tools that are efficiently integrated into the organization's competitive strategy to create long-term business value (Mäkinen \& Kourula, 2012, p. 661). According to Bansal et al. (2015, p. 70), implementing strategic CSR in governance, labor practices and decent work, workforce diversity, human rights, health and safety, environmental issues, product responsibility, affects a firm's core competences, requiring important changes to organizational structure. Once introduced and implemented, strategic initiatives such as environmental and social management systems or corporate governance practices, tend to have a long-lasting effect on the coporations' evolutionary trajectory and cannot be easily reversed. Due to thecomplexity and significance of these activities and regular interactions with stakeholders (Bansal et al., 2015, p. 70), strategic CSR is seen as an opportunity to create shared value (Martinuzzi \& Kumray, 2013, p. 425). In doing this, strategic CSR(with inside out and outside in dimensions) moves beyond good corporate citizenship and mitigating harmful value chain impacts to mount a small number of initiatives whose social and business benefits are large and distinctive (Porter \& Kramer, 2006, p. 10). Strategic CSR includes mission and vision statements (Lantos, 2001), and targets stakeholders, especially consumers, employees, and marketers. The aim is to include environment and society in strategic decisions and to open up an innovative potential. Processes must be adopted, employees have to be informed about the strategy, and a certain commitment to CSR is required. Therefore, the materiality is high.There are certain risks when integrating CSR into strategy, such as losing the position achieved in the market or upsetting business partners (Martinuzzi \& Kumray, 2013, p. 433-434). 


\section{Political CSR}

According to Scherer et al. (2014) globalization calls for a fresh view concerning the political role of business in society and its contribution to social innovations and the public good. They argue that these phenomena need to be embedded in a new concept of the business firm as an economic and political actor in market societies and as an actor that contributes to both private and public interests (Scherer et al., 2014, p. 148).

Despite Friedman (1970), Levitt (1958) and others arguments that the role of the business is to make profit and that it's the government's obligation to provide for all kinds of individual and community needs (Lantos. 2001, p. 613) political decisions are no longer exclusively made by the state (Baur \& Palazzo, 2011, p. 586). In cases when the state fails in regulating the economy, dealing with transnational social and environmental problems, providing public goods (education, public health, and infrastructure), administering citizenship rights, it does not serve the public interest (Matten \& Crane, 2005; Schereret al., 2014). Corporations and NGO's often step in and fill the governance void and take responsibility for issues of public concern (Teegenet al., 2004) in taking over certain functions with regard to the protection, facilitation and enabling of citizen's social, civil and political rights - formerly an expectation placed solely on the government (Matten \& Crane, 2005). These are not necessarily made manifest in national laws but in several regulatory standards developed by the Global Reporting Initiative, the UN Global Compact, ISO 14000 series or the Social Accountability 8000 for CSR reporting. These initiatives contribute to public health, education, social security, and the protection of human rights, or engage in self-regulation to fill the gaps in legal regulation and to promote societal peace and stability (Matten \& Crane, 2005). This goes beyond the instrumenal and strategic view of CSR in order to develop a new understanding of global politics where private actors such as corporations and civil society organizations play an active role in the democratic regulation and control of market transactions (Scherer \& Palazzo, 2011, p. 901). Therefore, CSR in this context should be understood as a political responsibility (Baur \& Palazzo, 2011, Gilbert \& Rasche, 2007; Reynolds \& Yuthas, 2008; Scherer et al., 2006; Scherer \& Palazzo, 2007). In line with this clarification "political CSR encompasses activities whereby CSR is a deliberate attempt to usurp government regulation, CSR related activities that are geared solely towards responding to government policy and also CSR related activities where firms recognize their impact on society and their social responsibilities in a way that has a clear 
impact on regulation, even though this may not be the intended aim of the activity" (Frynas\& Stephens, 2014, p. 3-4).

\section{Methodology}

This study examines corporate communication or corporate social responsibility directors qualitative attitudes about their CSR conceptions and there role in CSR. For this empirical data was collected by using a qualitative research method in taking a cross sectoral case based approach with six industries. These sectors were computer hardware, low voltage electric installations, retailer, food and agriculture, drinks and beverages, and insulation materials. Table 2 demonstrates the corporations' strategic position, industry, label and gender of the participants.

Table 2. Corporations and Departments

\begin{tabular}{|l|l|l|l|l|}
\hline $\begin{array}{l}\text { Cor } \\
p .\end{array}$ & $\begin{array}{l}\text { Strategic } \\
\text { Position }\end{array}$ & Industry & Label of Person & Gender \\
\hline C1 & Transnational & Computer Hardware & CSR Programs Director & Male \\
\hline C2 & Transnational & Electric Installations & $\begin{array}{l}\text { Corporate Communications and } \\
\text { CSR Director }\end{array}$ & Male \\
\hline C3 & Transnational & Retail & Corporate Relations Director & Female \\
\hline C4 & National & Food and Agriculture & $\begin{array}{l}\text { Media and Public Relations } \\
\text { Director }\end{array}$ & Male \\
\hline C5 & National & $\begin{array}{l}\text { Drinks and } \\
\text { Beverages }\end{array}$ & $\begin{array}{l}\text { Corporate Communications } \\
\text { Manager }\end{array}$ & Female \\
\hline C6 & National & Insulation Materials & Technical Marketing Manager & Male \\
\hline
\end{tabular}

Findings were collected from in-depth interviews with communication directors or other corporate leaders contacted through the social network site LinkedIn. These professionals were initially approached with an explanation of the research in emphasizing that their company will be mentioned only in terms of size and industry. Interviews were recorded and lasted between 17 and 30 minutes via smartphone. The authors approached 35 professionals for interviews and gained access to six. One participant preferred to give the replies in written format. The interviews were conducted in April and May 2015 in Turkey and based on a selfadministered questionnare to distinguish betweeninstrumental, strategic and political CSR. These key themes were also used as a guide structure to define the practitioners' practices and roles. So the 
interviews based around a common set of questions like the CSR functions positionwithin the corporation, the factors that determine the firm's CSR understanding and policies, the role for public relations efforts in CSR, role of the primary stakeholder for CSR campaigns, the role for NGOs in corporations CSR policies, and the tools used for the communication of CSR practices.

\section{Findings}

\section{Corporations and their CSR Definition}

The lack of a widely accepted CSR definition remains a significant challenge for theorizing and defining CSR. In defining CSR, participantsexpressed their companies enthusiasm for CSR and mentioned different aspects of social responsibility. Participants from transnational corporations defined social responsibility asto think about future generations (C2), as is being a good neighbour (C3), returning what is gained from the society (C3), in a permanent, consistent, sustainable and measurable way (C3). Others from national corporations defined it as every kind of service for social interests (C4), as national development and social enterprise (C5) or creating awareness emerged as the leading notions associated with CSR (C6).

Participants did not express any differentiation between their personal view and the CSR policy of the corporation. The company policies differed according to the companies strategic position.A male CSR programs directorfrom a transnational corporation said "that globally prepared programs for economic and social development are implementednationally" $(\mathrm{C} 1)$. Whereas a male, technical marketing manager with 15 years' experience said that CSR activities are not policy driven, but formalized in more pragmatic terms (C6). A manager in his 50 's from a national corporation which was originally a farmers cooperative, illustrates that CSR is the "raison d'etre of the company" (C4). Likewise a corporate communications and CSR director from a transnational corporation said, "the sine qua non of sustainability is social responsibility... All companies like people must emphasis sustainability and must think of future generations. In fact, we deal with this approach the organizations' social responsibility. To carry out activities without compromising the needs of future generations we feel compelled to bring social responsibility practices into life"(C2). 


\section{CSR and Philanthropy}

Participants clarified their understanding of CSR.They differentiated CSR from philanthropy by being modern, being the organizations' responsibility for the society and by being measurable. Exemplary quotations from the interviews are set out in Table 3.

Table 3. CSR vs. Philanthropy

\begin{tabular}{l|l} 
CSR & Philanthropy \\
\hline Influences society, community and the future & Influences individuals \\
Should have measurable targets & Difficult to measure \\
Modern & Traditional \\
Organizational responsibility & Individual contribution \\
Should be communicated with stakeholders & Should not be "advertised" \\
Strategic policies & Charitable events
\end{tabular}

A participant from a transnational corporations, electric installations industry said, "philanthropy is an approach that touches on something. We see CSR as a concept that reflects the whole community, even the future. Philanthropy is very difficult to measure. We believe that we can measure CSR, so from the first day of the project we set specific performance indicators. We measure these annually with a number of parameters. But in philanthropy it is not possible to do it that way. It happens in the form of momentary and individual touches..." (C2).

A female corporate communication director in her 40's from the retail industry said that, "since the company was founded in 1992, various charitable events have been implemented. But CSR policies took place in the 2000's, where we first created "Family Clubs" for training skills to women and customers in agreement with the public education centers. English language courses, vocational training, healthy life, exercises, hyperactivity and many more courses were offered without any charge" (3).

A male media and public relations director in his 50's from a Turkish cooperative said that, "social responsibility embraces the whole society, but philanthropy is about the personal contributions of individuals" (4). 


\section{CSR policies and the Role of NGOs}

All participants agree on the importance of collaboration with NGOs. The main reason is that NGO's provide a network through which companies can reach people and groups. This is important not only for the proper and effective distribution of the goods or services produced by the CSR campaign but also for the publicity of the projects and the corporations. Especially national NGO's are the best organizations to reach local people. A female corporate communication director stated that:

"While we are trying to bring our CSR projects to large groups, we cannot ignore the use of existing information, expertise and network of NGOs. This would mean, that we waste our resources. If we don't collaborate with the efficient NGO's in Western Turkey, we can neither keep track of public opinion, nor communicate our projects as much as we want to" (C3).

The importance of the local NGO's is also emphasized by a corporate communication manager in her 30's from the drinks and beveragesindustry who said,

“... being an Istanbul based company, we cannot be presented at every location in Turkey. Local NGO's are there at the field, so they manage and ensure the sustainability of the project. In addition, NGO's lead the projects in creating social value" (C5).

A Media and Public Relations Director from the food and agriculture industry in his 50's said, "we share all the services with local NGO's and political parties, so we're together with them. If you want to embrace the whole society elected administrators form the community and NGO's should be embraced. We see it as an obligation" (C4).

Likewise, a CSR Programs Director from the comuputer hardware industry and a Corporate Communications and CSR Director from the electric installations industry emphasized the importance of local NGO's by applying global policies locally $(\mathrm{C} 1, \mathrm{C} 2)$.

\section{Public Relations Efforts in CSR}

The interviewed communication and CSR professionals insist that CSR activities should not be managed from the PR department, and agree on the need for communication of CSR that should have been done by the PR department. The communication efforts are seen appropriate only when they contribute to the communicative aspect of the campaign especially in conveying the campaigns' messages and announcements. A femal participant maintained that, 
“with proper PR, CSR projects may reach more people. This is not only good for the reputation of the company. If you have a pure CSR project you can reach more people by running media relations. Perhaps those who need the services you provide may get informed about your project through the media and contacts you" (C5).

Likewise a Corporate Relations Director(C3) also disapproved using CSR as a means of publicity and advertisement and emphasized the need for communication only to make the project be beneficial to larger numbers of people.

"CSR is not a part of PR. Certain companies still develop CSR projects under the general strategies of $P R$ in order to develop their publicity and reputation. However, this is a rather outmoded approach. We do not do this."

The same participant added that communication is necessary not to utilize it for publicity but to take on the responsibility of the projects in public.

A certain degree of visibility is required in undertaking the responsibility. The firm's logo must be on the donation packs so that if there emerges any problem, people should know whom to turn to. Here, the issue at stake is to own, not to advertise. In every respect, CSR surely helps building a positive image. However, for our company at least, CSR is not the main instrument for attaining visibility. Consequently, in the relation between CSR and PR, the second should not have primacy.

The only participant that did not make any distinction between CSR and PR was the Media and Public Relations Director. He said that,CSR and PR"are integral and inseparable. PR is part and a pioneer of all our CSR efforts" (C4).

\section{CSR Communication}

Participants from transnational companies' said that the CSR communication efforts are produced and planned in-house, within the companies own departments. A Corporate Relations Director said that, “... the corporate relations department organizes CSR...” (C3). Similarly, a director from the Corporate Communications and CSR department said that “...CSR is fully managed by the corporate communications and CSR department...” (C2). Apparently the more detailed departmental structure of the transnational companies allows them to manage their projects without outsourcing.Contrary all participants from the national companies said that they prefer to work with a communication or sustainability development consultancy firm not only for CSR practices but also for other communication practices. 
All participants mentioned the use of social media for their CSR communication efforts. however except for $\mathrm{C}$, social media was neither the single nor the primary medium for their communication efforts. Five companies try to use the traditional media as much as they can. They use press releases, tv appearances, interviews and even bilboards to communicate their CSR projects with the public. Companies that mentioned internal stakehoders (employees and constituents) as their primary stakeholders depend more on mailing lists for communication. C6 mentions the use of celebrity endorsement in their awarenes raising campaigns.

A transnational corporation from the retail industry (C3) focuses particularly on interpersonal communication. For this, it values NGO-company relations more than the other participants.

By means of NGOs, we enter a network of relations. We take part in certain platforms where we can establish face-to-face relations. These relations help us to discover new ideas and come across with valuable partners. The relations we breed also serves as a channel for feedback on our CSR programs.

A participant from the national corporation (C5) states that they utilize all communication means to share CSR information with their employees as internal stakeholders. For external stakeholders, they use traditional media primarily. They organize press trips to the cities, run their projects and arrange press conferences and special interviews.

\section{Conclusion}

During the past decades corporate social responsibility has evolved rapidly as stakeholders have become more organized and powerful in affecting the way corporations do business. This could be attributed to factors like globalization, fast access to information and sustainability. Key stakeholders now have much more knowledge available through the internet and social media tools, they can be more informed about the companies whose products they purchase or services they use. It is also well kown that corporations who perform CSR enhance reputation, save costs, improve innovation, build effective relationships with key stakeholders. This research focuses on the CSR directors or managers' conception of CSR in transnational and Turkish national corporations within the terminology of instrumental, strategic and political CSR.

The findings of this study show that among the participants there is a strong commitment to corporate responsibility. At the conceptual level CSR is explained as the sine qua non of 
sustainability or the raison d'etre of the company, which is managed at the operational level in implemeting several economic, social and environmental progams to several stakeholders. However, CSR programs and especially budgets are still far from being transparent. The ambiguity over the CSR programs are reflected in the unvillingness of the professionals to participate in an academic research. Of the $35 \mathrm{CSR}$ professionals, data were collected from interviews with the corporate communication or corporate social responsibility directors/managers of three transnational and three large Turkish national corporations representing six industries. The study reflects the differences of locations and functions of CSR within corporations. It is noteworthy that in transnational corporations CSR is more located as an interest of the corporate programs, corporate communications and corporate relations department where the commitments are structural and routinezed. In national corporations CSR is more located as an area of interest in the media and public relations department or marketing department with more customer orientated programs and limited influence. There are also differences in the label of persons who are responsible for the CSR efforts of the corporations. In transnational corporations CSR policies and strategies are managed by a CSR director/manager or corporate relations director who plays an important role in defining and implementing CSR strategies. In contrast in national Turkish corporations CSR is managed by the media and public relations director, corporate communications or technical marketing manager.

In addition to these findings the research shows that while transnational corporations' CSR communication efforts are produced and planned in-house, within the companies related departments, national corporations prefer to work with a communication or sustainability development consultancy firm. Customers and employees are commonly recognized as the most important category of stakeholders corporations have to consider. To communicate the CSR programs and activities with external stakeholders like customer, retailer, and shareholders many CSR communication tools, including press releases, tv and press interviews, magazines, press trips and conferences, bilboards, social media, and celebrity endorsement are used. For internal stakeholders like employees, corporations use mailings and interpersonal communication, roll up banner, posters, intranet and social media.It is noteworthy that none of the participants mentioned corporate web sites and social responsibility reports.According to Esrock and Leichty (1998, p. 309) a web site has thepotential to influenceagenda. Corporations 
can use the web sites effectively to interact with audiences and to provide information directly to individuals without having to pass through the gatekeepers of the news media. Another important channel for communicating CSR activities are social responsibility reports. Transnational corporations use these reports to communicate theCSR activities and initiatives with particular interest groups. It should be mentioned that in Turkey, social responsibility reports are still limited in quantity and quality. Companies do not report their CSR activities because of the lack of interest from their stakeholders in reporting and also companies are unfamiliar with reporting their CSR activities as they prepare their financial reporting. That's why CSR reporting should be promoted in Turkey by different channels like the government, the media, or the NGO's (Orhaner \& Dogan, 2010, p. 48). Turkey, as a developing country, should increase social responsibility reporting to maintain and enhance the economic success in terms of responsibility, transparency and accountability (Hoştut \& Deren Van Het Hof, 2015, p. 131). So corporations should use multiple channels and efforts to ensure that CSR information isaccessible and interpretable to stakeholders and the public. Thus, CSR communication is not simply a one-way public information model of exchange, nor is it just a company's strategic management. It is or should be a two-way communication between companies and their stakeholders, with a focus on mutual understanding and shared values (Tenchet al., 2014, p. 6). Corporate philanthropy is an umbrella term which encompasses a number of different values, interests, mindsets and alternative approaches which are based on a variety of perceptions shaped by cultural, contextual and professional factors (Leisinger, 2011, p. 4). It represents a voluntary and discretionary manifestation of CSR that differs in kind from the obligatory conformance with economic, legal, or ethical dimensions of CSR (Carroll, 1979). This nature of philanthropic activity (doing good above and beyond what is expected) maylead to imputations of exemplary, as opposed to merelygood, behavior (Wood \& Logsdon, 2002; Godfrey, 2005, p. 778). The findings show that participants from both transnational as well as national corporations make clear differences between philanthropy and CSR. Philanthropic initiatives are typically described in terms ofbeing traditional, difficult to measure, and charitable short time contributions with short time costs which happens mostly in the form of individual touches instead of strategic actions. In contrast CSR is defined as organisational responsibility with strategic policies which is measureable and should be communicated with key stakeholders. The findings also show that all Turkish national corporations conduct philanthropic contributions within the awareness of the top management. 
They carry out their charitable activities through foundations (vakif), grants and donations. Philanthropy is needs-oriented and fits into Schwartzand Carroll's (2003, p. 515) category of purely ethical because it has nodirect or indirect economic, legal orpolitical considerations. Contrary to these findings the philanthropic contributions from transnational corporations have been found relatively little.

Partnerships between business and NGOs in the pursuit of CSR have become increasingly prevalent in recent years (Poret, 2014, p. 20). According to Van den Berghe and Louche (2005, p. 427) corporations are facing a new invisible hand, that is, nonmarket forces exerted by NGOs, media, trade unions and others. The authors define it as a powerful force that reigns in the business world and definitely opens-up the black box of board and management trade-offs and decision-making. Corporations form partnerships with NGOs because NGOs promotes ocietalactions, provide technicala ssistance, elaborate certification schemes, promote and design CSR standards as well as management and reporting processes, and participate in CSR monitoring and auditing (Poret, 2014, p. 15-16). The findings of this investigation show that in the CSR context, corporations agree on the importance of the collaboration with NGOs especially for their stakeholder dialogue. The reason for this is, NGO's provide the network and the information through which companies can reach localpeople and groups. This is important not only for the proper and effective distribution of the services produced by the CSR campaign but also for the publicity of the projects.

Clark (2000) argues that public relations and CSR have similarities, which provide clues to their integration and increased joint effectiveness. Both disciplines are seeking to enhance the quality of the relationship of an organization among key stakeholder groups and both disciplines recognize that to do so makes good business sense (Clark, 2000, p. 376). On the other hand, it has been argued that business loses the opportunity to benefit from CSR, if it addresses CSR in public relations and media campaigns (Pollach et al, 2012, p. 205). The most common response would be neither strategic nor operational but cosmetic: the centerpieces of which are often glossy CSR reports that showcase companies social and environmental good deeds (Porter \& Kramer, 2006, p. 2-3). The findings of this investigation supports that CSR activities should not be managed from the PR department.But the participants agreeon the need for communication of CSR done by the PR department when it contributes to the 
communicative aspect of the campaign especially in conveying the campaigns' messages and announcements.

So this study shows, that all interviewed CSR directors or managers are aware of the importance of CSR for their corporations sustainability as well as for the society. They make clear differentiations between CSR and philanthropy, and they are conscious in working with NGO's or third parties. CSR in transnational corporations can be defined as strategic, that goes beyond the common understanding of customer orientated short time issue management, persuasion and financial performance. The strategic view is defined as a long time perspective, planned, implemented and evaluated to create business value. Two of three Turkish national corporations' conception can be defined as a stage between instrumental and strategic, because CSR in these corporations is more customer orientated with limited or short time influence at the one side, but also implemented for sustainability and to create business value on the other side. A Turkish national farmers cooperatives' consideration can be defined as political CSR. The corporation was established in 1952 and consists of 60 thousand partners and 900 thousand farmers with the aim of setting up the needs of the community and the economic development. Politcal CSR comprises issues of public concern with long time perspectives, adjustable resources, and innovative policies. The corporation cooperates with stakholders and the CSR strategy is integrated in the corporations identity to create shared value. It can be concludedthat in the beginning corporations may choose to start with limited resources, defensive policies and short time perspective as it is described in instrumental CSR first and then expand their conception on more formal and strategic or political CSR over time.

Finally, the size and the mangement structure of a corporation affects the conception of CSR. So, it is found that beside transnational corporations also large Turkish national corporations implemet formal CSR strategies. The interviews indicate that the differences in conceptions of CSR within the terminology of instrumental, strategic and political are useful. These conceptions were easily observable and operational not only in transnationals but as well as in national corporations. Along with large corporations, the role of small and medium enterprises (SME) is also crucial for Turkey which constitute $99.9 \%$ of all corporations. In order to understand the dynamics of CSR in SME's, the CSR conceptions, definitions, strategies and implementations of SME's are particularly important. 


\section{References}

Ararat, M. (2008). A development perspective for "Corporate Social Responsibility: Case of Turkey. Corporate Governance, 8(3), 271-285.

Bansal, P., Jiang, G. F., \& Jung, J. C. (2015). Managing responsibly in tough economic times: Strategic and tactical CSR during the 2008-2009 global recession. Long Range Planning, 48, 69-79.

Barnett, M., \& Salomon, R.(2006). Beyond dichotomy: The curvilinear relationship between social responsibility and financial performance. Strategic Management Journal, 27, 1101-1122.

Baur, D., \& Palazzo, G.(2011). The moral legitimacy of NGOs as partners of corporations. Business Ethics Quarterly, 21(4), 579-604.

Bhattacharyya, S.S.(2010). Exploring the concept of strategic corporate social responsibility for an integrated perspective. European Business Review, 22, No. 1, 2010, 82-101, doi: 10.1108/09555341011009025

Carroll, A.B. (1979). A three-dimensional conceptual model of corporate social performance. Academy of Management Review, 4(4), 497-505.

Chen, J.C., Patten, D.M. \& Roberts, R.W.(2008). Corporate charitable contributions: A corporate social performance or legitimacy strategy? Journal of Business Ethics, 82(1), $131 \mathrm{e} 144$.

Clark, C. E. (2000). Differences between public relations and corporate social responsibility: An analysis. Public Relations Review, 26(3), 363-380.

Committee Encouraging CorporatePhilanthropy.(2014). Giving in numbers: 2014 Edition. Retrieved on November 29, 2014, from www.cecp.co/researchorconferenceboard.org/publications

Dahlsrud, A.(2008). How corporate social responsibility is defined: An analysis of 37 definitions. Corporate Social Responsibility and Environmental Management, 15, 1-13. doi: 10.1002/csr.132.

Elving, W. J. L., Golob, U., Podnar, K., Ellerup-Nielsen, A., \& Thomson, C. (2015). The bad, the ugly and the good: new challenges for CSR Communication. Corporate Communications: An International Journal, 20(2), 118-127. doi: 10.1108/CCIJ-022015-0006 
Esrock, S., \& Leichty, G.(1998).Social responsibility and web pages: Self presentation or agenda setting? Public Relation Review, 24(3), 305-319.

Friedman, M. (September 13, 1970). The social responsibility of business is to increase its profits. New York Times Magazine, 32-33, 122-24.

Frynas, J. G., \& Stephens, S. (2014). Political corporate social responsibility: reviewing theories and setting new agendas. International Journal of Management Reviews, 1-27. doi: 10.1111/ijmr.12049

Gilbert, D. U., \& Rasche, A. (2007). Discourse ethics and social accountability: The ethics of SA 8000. Business Ethics Quarterly, 17, 187-216.

Gocenoglu, C., \& Onan, I.(2008). Turkey social responsibility report baseline report.

Retrieved on May 28, 2014, from http://www.tr.undp.org/content/turkey/en/home/ library/poverty/corporate-socialresponsibility.html

Godfrey, P. C. (2005). The relationship between corporate philanthropy and shareholder wealth: A risk management perspective. Academy of Management Review, 30, No. 4, 777-798.

GRI. (2015). Sustainability disclosure database. Retrieved on October 20, 2015, from http://database.globalreporting.org/

Hoştut, S., \& Deren Van HetHof, S. (2015). A decadeintosustainabilityreporting in Turkey. In: A. Catellani, A. Zerfass, \& R. Tench (Eds.), Communication Ethics in a Connected World: Research in Public Relations and Organisational Communication. Brussels: Peter Lang Publishing, 115-134.

Husted, B., \& Salazar, J. D. J. (2006). Taking Friedman seriously: Maximizing profits and social performance. Journal of Management Studies, 43(1), 75-91.

Jones, T. M., \& Wicks, A. C. (1999). Convergent stakeholder theory. Academy of Management Review, 24, 206-221.

Lantos, G. P. (2001). The boundaries of strategic corporate social responsibility. Journal of Consumer Marketing, 18(7), 595-632.

Leisinger, K. M., \& Schmitt, K. (2011). Corporate responsibility and corporate philanthropy. Retrieved on November 04, 2015, from http://www.un.org/en/ecosoc/newfunct/pdf/ leisingerschmitt_corporate_responsibility_and_corporate_philanthropy.pdf

Levitt, T. (1958). The dangers of social responsibility. Harvard Business Review, September October, 41-50. 
Mäkinen, J., \& Kourula, A.(2012). Pluralism in political corporate social responsibility. Business Ethics Quarterly, 22(4), 649-678.

Martinuzzi, A., \& Krumay, B.(2013). The good, the bad, and the successful - how corporate social responsibility leads to competitive advantage and organizational transformation. Journal of Change Management, 13(4), 424-443, doi: $10.1080 / 14697017.2013 .851953$

Matten, D., \& Crane, A.(2005). Corporate citizenship: Toward an extended theoretical conceptualization. Academy of Management Review, 30(1), 166-179.

Orhaner, B., \& Doğan, F.(2010). CSR Baseline Report Turkey. Retrieved on November May, 28, 2014, from www.kssd.org

Pollach, I., Johansen, T. S., Ellerup Nielsen, A., \& Thomsen, C. (2012). The integration of CSR into Corporate Communication in large European companies. Journal of Communication Management, 16(2), 204-216. doi: 10.1108/13632541211217605

Poret, S. (2014). Corporate-NGO partnerships in CSR activities: why and how? Retrieved On November 06, 2015, from https://hal.archives-ouvertes.fr/hal-01070474/document

Porter, M. E., \& Kramer, M. R.(2006). Strategy and society: The link between competitive advantage and corporate social responsibility. Harvard Business Review, 84(12), 78-92.

Reynolds, M. A., \& Yuthas, K. (2008). Moral discourse and corporate social responsibility Reporting. Journal of Business Ethics, 78(1/2), 47-64.

Scherer, A.G. \& Palazzo, G.(2011). The New Political Role of Business in a Globalized World: A Review of a New Perspective on CSR and its Implications for the Firm, Governance, and Democracy. Journal of Management Studies, 48(4), June 2011. doi: 10.1111/j.1467-6486.2010.00950.x

Scherer, A. G., \& Palazzo, G. (2007). Toward a political conception of corporate responsibility: Business and society seen from a Habermasian perspective. Academy of Management Review, 32, 10961120.

Scherer, A. G., Palazzo, G., \& Bauman, D. (2006). Global rules and private actors: towards a new role of the transnational corporation in global governance. Business Ethics Quarterly, 16, 505-532.

Scherer, A. G., \& Palazzo, G., \& Matten, D. (2014). The business firm as a political actor: A new theory of the firm for a globalized world. Business \& Society, 53(2), 143-156. doi: $10.1177 / 0007650313511778$ 
Schwartz, M. S., \& Carroll A. B. (2003). Corporate social responsibility: A three domain approach. Business Ethics Quarterly, 13(4), 503-530.

Teegen, H., Doh, J. P., \& Vachani, S. (2004). The importance of nongovernmental organizations (NGOs) in global governance and value creation: An international business research agenda. Journal of International Business Studies, 35, 463-483.

Tench, R., Sun, W., \& Jones, B. (2014). Introduction: CSR communication as an emerging field of study. In: R. Tench, \& W. Sun, (Eds.), Communicating Corporate Social Responsibility: Perspectives and Practice. UK: Emerald Group Publishing Limited,321.

Tench, R., Sun, W., \& Jones, B. (2012). The challenging concept of corporate social irresponsibility: An introduction. In: R. Tench, W. Sun, \& B. Jones (Eds.), Critical Studies on Corporate Responsibility, Governance and Sustainability. UK: Emerald Group Publishing Limited, 3-22.

The European Commission. (2011). Corporate social responsibility: A new definition, a new agenda for action. Brussels, MEMO/11/730.

Van Den Berghe, L., \& Louche, C. (2005). The link between corporate governance and corporate social responsibility in insurance. The Geneva Papers on Risk and Insurance, 30, 425-442.

Vogel, D. (2005). The market for virtue: The potential and limits of corporate social responsibility. Washington, DC: Brookings Institute.

Wood, D. J., \& Logsdon, J. M. (2002). Business citizenship: From individuals to organizations. Business Ethics Quarterly, 12, 59-94. 